\title{
Stable isotope discrimination factors of omnivorous fishes: influence of tissue type, temperature, diet composition and formulated feeds
}

\author{
J. Robert Britton • Georgina M. A. Busst
}

Received: 2 June 2017/Revised: 24 October 2017 / Accepted: 27 October 2017/Published online: 11 November 2017

(C) The Author(s) 2017. This article is an open access publication

\begin{abstract}
Application of stable isotope data to trophic studies requires understanding of factors influencing the isotopic discrimination factor $(\Delta)$ between consumers and their prey resources. This is missing for many omnivorous species, despite their diet and environment potentially impacting $\Delta$. The effects of temperature, diet (including formulated feeds) and tissue type on $\Delta^{13} \mathrm{C}$ and $\Delta^{15} \mathrm{~N}$ were thus tested experimentally. A temperature experiment exposed three species to identical diets at 18 and $23^{\circ} \mathrm{C}$, whereas a diet experiment exposed one species to four diets at $18^{\circ} \mathrm{C}$. At $23^{\circ} \mathrm{C}, \mathrm{C}: \mathrm{N}$ ratios, $\Delta^{13} \mathrm{C}$ and $\Delta^{15} \mathrm{~N}$ were generally elevated versus $18^{\circ} \mathrm{C}$. After lipid correction, tissue/species-specific differences at $23^{\circ} \mathrm{C}$ in $\Delta^{13} \mathrm{C}$ and $\Delta^{15} \mathrm{~N}$ were up to 0.73 and $0.54 \%$ o higher, respectively. Across the four diets, there were also significant differences in $\Delta^{13} \mathrm{C}$ and $\Delta^{15} \mathrm{~N}$ between a natural diet and diets based on formulated feeds. $\Delta^{13} \mathrm{C}$ and $\Delta^{15} \mathrm{~N}$ of muscle were 1.51 to $2.76 \%$ and 3.13 to
\end{abstract}

Handling editor: Michael Power

Electronic supplementary material The online version of this article (https://doi.org/10.1007/s10750-017-3423-9) contains supplementary material, which is available to authorized users.

J. R. Britton $(\varangle)$ · G. M. A. Busst

Department of Life and Environmental Sciences, Faculty

of Science and Technology, Bournemouth University,

Poole BH12 5BB, UK

e-mail: rbritton@bournemouth.ac.uk
$5.44 \%$, respectively. Highest $\Delta$ for both isotopes was from a formulated feed based on plant material that resulted in lower dietary protein content and quality. Thus, diet and environment fundamentally affected the isotopic discrimination factors and these factors require consideration within trophic studies based on stable isotopes.

Keywords Cyprinidae $\cdot$ Stable isotope fractionation $\cdot$ Stable isotope analysis $\cdot$ Mixing models

\section{Introduction}

The application of stable isotope data to ecology has substantially enhanced understandings of trophic relationships within and between species, including how invasive species impact native communities (e.g. Jackson et al., 2016; Copp et al., 2017) and trophic subsidies influence consumer diets (e.g. Bašić et al., 2015; Gutmann-Roberts et al., 2017). Their application has been enhanced by the development of 'mixing models' that estimate the diet composition of consumers from the stable isotope ratios of their prey (Phillips et al., 2001, 2014). For models to provide reliable dietary predictions requires accurate estimates of the stepwise isotopic change between the consumer and their prey (Boecklen et al., 2011), i.e. the isotopic 'discrimination' factor $(\Delta$; Martínez del Rio \& Wolf 
2005). The issues that affect discrimination factors within and between consumer species include the age and body size of sampled individuals, their diet composition, the tissues analysed and the sample preparations completed prior to analysis (Brush et al., 2012; Locke et al., 2013; Busst et al., 2015). There can be high uncertainty in the discrimination factors of many species (Moore \& Semmens, 2008; Elsdon et al., 2010; Busst \& Britton, 2016). This uncertainty and variability in discrimination factors between species and tissues thus suggest that commonly cited values (e.g. $\Delta{ }^{15} \mathrm{~N}: \quad 3.4 \pm 0.98 \%$; $\quad \Delta^{13} \mathrm{C}: \quad 0.39 \pm 1.3 \%$; Minagawa \& Wada, 1984; Post, 2002) might not always be appropriate to apply to mixing models.

Among consumer species, specific food items within their overall diet can substantially influence their discrimination factors (Caut et al., 2008; Greer et al., 2015). Invertebrate-based diets tend to have lower discrimination factors than diets with higher protein contents (McCutchan et al., 2003). In herbivorous fishes, $\Delta^{15} \mathrm{~N}$ in muscle has been recorded to be 5.25\% (Mill et al., 2007; Carassou et al., 2008). In the detrivore Prochilodus lineatus (Valenciennes, 1837), $\Delta^{13} \mathrm{C}$ varied between -1.9 and $3.6 \%$ and was between 3.3 and $5.7 \%$ for $\Delta^{15} \mathrm{~N}$ (Sacramento et al., 2016). For species that are highly omnivorous, such as fishes of the Cyprinidae family, discrimination factors of ${ }^{13} \mathrm{C}$ and ${ }^{15} \mathrm{~N}$ can be relatively low when fish have diets that are relatively high in fish protein (e.g. 2.0\% for both isotopes) but significantly higher when high in plant materials that are relatively low in protein (up to 5.6\% for $\Delta^{13} \mathrm{C}$ and $6.9 \%$ for $\Delta^{15} \mathrm{~N}$ ) (Busst \& Britton, 2016). These data allow testing of the 'protein quality hypothesis', which suggests that discrimination factors will increase as protein quality decreases, and the 'protein quantity hypothesis', which suggests that discrimination factors will increase as $\mathrm{C}: \mathrm{N}$ ratios decrease (i.e. as dietary nitrogen concentration decreases) (Pearson et al., 2003). Moreover, for omnivorous fishes that have mixed diets comprising animal and plant items, the varying proportions of these items could have potentially strong effects on their discrimination factors (Bastos et al., 2017). For example, in some cyprinid fish populations in recreational freshwater fisheries, some individual fish specialize on feeding on angler trophic subsidies based on formulated feeds containing marine-derived fishmeal, whilst others specialize primarily on natural prey (Bašić et al., 2015; Gutmann-Roberts et al.,
2017). The influences of these angling baits on discrimination factors are thus potentially important for trophic studies completed in freshwaters where there are high angling activity and consequent individual trophic specializations in their target species (Gutmann-Roberts et al., 2017).

Stable isotope data and discrimination factors are also dependent on the tissues analysed, with predictable differences apparent between fish muscle and fin tissue (e.g. Jardine et al., 2005; Sanderson et al., 2009; Tronquart et al., 2012), and scales (Busst et al., 2015; Busst \& Britton, 2016). In general, fin and scale stable isotope data are converted to muscle values for application to mixing models, as muscle data tend to more closely reflect diet composition (Grey et al., 2009). Temperature and food ration can also significantly influence discrimination, with Barnes et al. (2007) revealing that in bass Dicentrarchus labrax (Linnaeus, 1758) elevated temperatures resulted in higher $\Delta^{13} \mathrm{C}$, but lower $\Delta^{15} \mathrm{~N}$. In addition, Power et al. (2003) reported for zooplankton Daphnia magna Straus, 1820 and Hyalella sp., as temperature increased there were a general increase in $\Delta^{13} \mathrm{C}$ and a decrease in $\Delta^{15} \mathrm{~N}$, with this suggested to relate to the effect of temperature on habitat use, differential use of energy sources and differences in trophic position.

Whilst there has been considerable effort in determining discrimination factors for many species, in fishes these have tended to be biased towards marine fishes (e.g. Pinnegar \& Polunin, 1999; Mill et al., 2007; Sweeting et al., 2007a, b) and/or those with aquaculture interest (e.g. Zuanon et al., 2006). For freshwater fishes, such as those of the Cyprinidae family, there remains limited knowledge for most species on their discrimination factors and how these are affected by diet and temperature. Yet, this family comprises omnivorous species that include global invaders (e.g. carp Cyprinus carpio Linnaeus 1758, goldfish Carassius auratus (Linnaeus 1758)), are important in freshwater aquaculture (e.g. C. carpio) and are of high interest to recreational anglers (e.g. $C$. carpio, chub Squalius cephalus (Linnaeus 1758)) (Busst \& Britton, 2016; Guo et al., 2016; GutmannRoberts et al. 2017). Consequently, the aim here was to use model cyprinid species in controlled and semicontrolled conditions to experimentally determine the influence of temperature and diet composition on the $\Delta^{13} \mathrm{C}$ and $\Delta^{15} \mathrm{~N}$ in dorsal muscle, fin tissue and scales. The following hypotheses $(\mathrm{H})$ were tested: 
discrimination factors vary predictably between the analysed fish tissues $\left(\mathrm{H}_{1}\right)$; elevated temperatures result in higher $\Delta^{13} \mathrm{C}$ but lower $\Delta^{15} \mathrm{~N}\left(\mathrm{H}_{2}\right)$; discrimination factors vary according to diet, with differences apparent between natural diets and those including formulated feeds $\left(\mathrm{H}_{3}\right)$; and variation in discrimination factors with diet is consistent and explained by the quality and quantity of their protein content $\left(\mathrm{H}_{4}\right)$. Given that both fin tissue and scales can be collected from fishes non-lethally, then the results will also potentially provide support over their replacement of dorsal muscle in studies where destructive sampling is not feasible.

\section{Materials and methods}

Temperature-based experimental design

The temperature-based experiment was completed in controlled conditions in tank aquaria, with fish held in 90-1 tanks on flow-through filtration systems to maintain water quality $(\mathrm{pH} 7.5)$. The experimental design was based on exposing three fish species, $C$. carpio, C. auratus and S. cephalus, to a single food item at 18 and $23^{\circ} \mathrm{C}$ for 150 days. Consumers are generally considered to have equilibrated to their food resources in four to five half-lives, i.e. 94-97\% isotopic replacement in their tissues (Hobson \& Clark, 1992). General equations from Thomas and Crowther (2015) suggested that the experimental fishes would have half-lives for $\delta^{13} \mathrm{C}$ of 30 days and for $\delta^{15} \mathrm{~N}$ of 32 days, and thus the experimental period of 150 days meant that isotopic equilibrium should have been reached at its conclusion. This duration was also broadly representative of the length of fish growth seasons in temperate regions when water temperatures would be expected to be at least $18^{\circ} \mathrm{C}$ (Britton, 2007).

The fishes used in the experiment were sourced from pond aquaculture where their diets had been a mix of natural foods (e.g. macroinvertebrates), supplemented with some formulated feeds. Eight fish were used per species and temperature, except $S$. cephalus where $n=7$. For each species and temperature combination, the fish were held within the same tank. The $18^{\circ} \mathrm{C}$ temperature was achieved by this being the ambient temperature of each flow-through system (range $17.9-18.4^{\circ} \mathrm{C}$ ); $23^{\circ} \mathrm{C}$ was achieved by elevating temperatures in an individual system via water heaters (range $22.7-23.2^{\circ} \mathrm{C}$ ). Temperatures were monitored in tanks using temperature loggers (TinyTag TGP-4017) that recorded hourly. A 16:8 h light:dark cycle was used. Each fish was measured (fork length, $l$, nearest $\mathrm{mm}$ ) and weighed ( $W$, nearest $0.1 \mathrm{~g}$ ) at the start of the experiment (Table S1), and a passive integrated transponder (PIT) tag inserted to enable all fish to be identified individually. Their fixed diet was a high-grade fishmeal pellet sourced from aquaculture that had been crushed into small particles ( $<1 \mathrm{~mm}$ diameter); it comprised $45 \%$ protein, $10 \%$ fat, $1.4 \%$ crude fibre and $5.8 \%$ ash, and the protein source was marine fish (Busst et al., 2015). A formulated feed was preferred to natural prey. This was because the experimental diet needed to have minimal isotopic variation in order to determine the influence of temperature on discrimination, with this assumed to be more easily achieved using a single, homogenous batch of a prepared food (Busst \& Britton, 2016). The crushed pellet was fed daily ad libitum.

At the end of the experiment, the fish were removed from the tanks, re-measured and weighed, euthanized (anaesthetic overdose, MS-222), and samples taken of dorsal muscle, pelvic fin tissue and scales (taken from below the dorsal fin and above the lateral line). Samples of the feed used were also taken. The length and weight increments of the individual fish were determined for use as a proxy of food ration size over the course of the experiment, based on the assumption that fish with higher increments accessed larger feed rations. As length and weight increases are significantly correlated in fishes, then only length increment was used in subsequent analyses.

\section{Dietary-based experimental design}

In this experiment, a single fish species was used, $C$. auratus (sourced from the same aquaculture site as the fish in the temperature experiment), and exposed to four diets (D1-D4) that varied in their approximate proportions of natural prey items and two formulated feeds (Table 1). The experiment lasted for 100 days, representing approximately 3.5 isotopic half-lives for the starting sizes of the fish used (Thomas \& Crowther, 2015).

Among the diets, two different formulated feeds were used. The first was 'Wheatgerm pellets' ('WG'; $2 \mathrm{~mm}$ diameter) that comprised $20 \%$ protein, $6 \%$ fat 


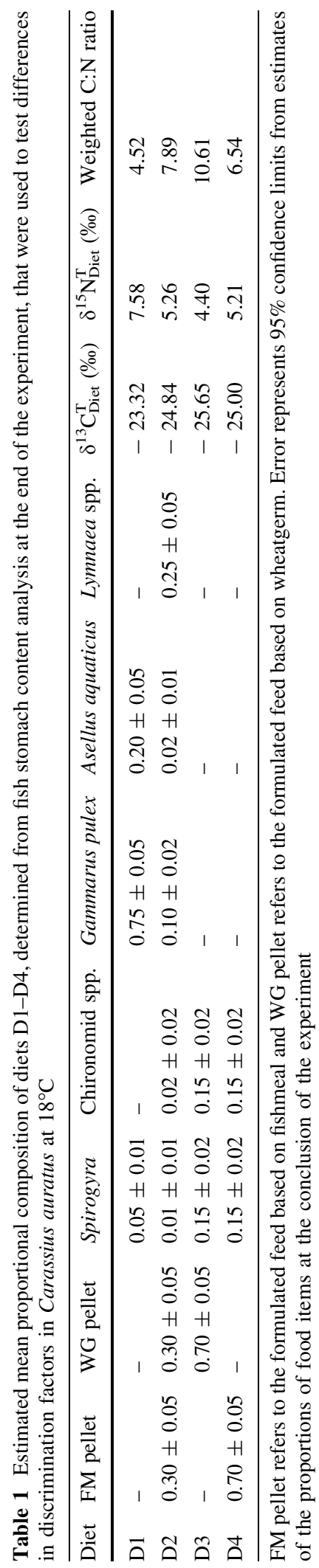


(as oil), $2.5 \%$ crude fibre and $2.5 \%$ ash, and whose base ingredient was plant material (Nishikoi Aquaculture, available from http://www.nishikoi.com/ pond-food/nishikoi-wheatgerm, last accessed 1st May 2017). The second was a fishmeal-based pellet ('FM') produced for sport angling that had constituents of $45 \%$ protein and $20 \%$ fish oil pellets (2 mm diameter). Diet D1 was based entirely on natural prey items, whereas D2-D4 were based on a combination of natural prey items and formulated feeds, where Diet D2 used both formulated feeds, D3 used WG, and D4 used the other formulated feed ('FM').

To achieve the exposure to the different prey items in D1-D4 (Table 1), outdoor mesocosm ponds were used, based on the assumption that the fish would eat similar proportions of the food items. Three fish were used per mesocosm, with three replicates used per diet ( $n=9$ fish per diet). Each pond was 2501 in volume, had a gravel substrate ( $6 \mathrm{~mm}$ diameter), a corner filter and oxygen supply to maintain water quality, and was seeded with a random mix of macroinvertebrates from a local stream (including Asellus aquaticus (Linnaeus, 1758), Gammarus pulex (Linnaeus, 1758) Lymnaea spp.), with Chironomid larvae and filamentous algae (primarily as Spirogyra spp.) colonizing naturally. These species were allowed to establish for 12 weeks prior to the release of the fish. The proportions of pellets to the diets of D1-D4 were estimated from using their known quantities fed daily that was based on a feeding rate of $1.0 \%$ fish starting weight. The proportions of natural prey in their diets were estimated from their stomach contents at the conclusion of the experiment, determined via dissection and microscopy, with cross-checking of the validity of the estimates through comparison with the composition of the macroinvertebrate community present at the start and the end of the experiment in each mesocosm (Table 1). Note that in diets $\mathrm{D} 3$ and D4, no G. pulex, A. aquaticus or Lymnaea spp. were recorded before or after the experiment in any of their replicates, but were in D1 (except Lymnaea spp.); all these species were, however, present in D2 (Table 1). Also note that the diet composition of individual fish were not measured during the experiment via stomach flushing, as their repeated capture and handling, relatively small body size and lack of a true stomach would have meant that the procedures were likely to have compromised their welfare. The 100-day experimental period was used as, after this period, the mean daily water temperatures in the mesocosms started to fall below $18^{\circ} \mathrm{C}$, as determined by in situ temperature loggers (TinyTag TGP-4017). Mean temperature over the 100 days was $18.2 \pm 0.8^{\circ} \mathrm{C}$.

At the end of the experimental period, the mesocosms were drained and fish removed. The fish were re-measured and weighed, euthanized (anaesthetic overdose, MS-222), and samples taken of dorsal muscle, pelvic fin tissue and scales. Concomitantly, triplicate samples of the pelleted feeds were taken, plus macroinvertebrate and filamentous algae samples were taken from each drained mesocosm, where a macroinvertebrate sample comprised between 4 and 6 individuals. Zooplankton was also sampled for, but abundances were negligible. As per the temperature trial, the length increments of the fish were calculated for use in subsequent analyses.

\section{Stable isotope analysis}

For their preparation for application to stable isotope analysis, fin clips and dorsal muscle were rinsed with distilled water; scales were lightly cleaned with distilled water to remove mucus, and their outer portion removed with dissection scissors and used, as this represents the most recent scale growth and thus, isotopically, the individual's most recent diet (Grey et al., 2009; Bašić et al., 2015). As the fish used were generally small, then between 1 and 3 scales were used per fish to provide sufficient material for the analysis. The scales were not acid treated to remove carbonates from the scales. This was because whilst there is some conjecture within the literature over whether this procedure is necessary for scales (e.g. Hutchinson \& Trueman, 2006; Sinnatamby et al., 2007), even where this is completed, then the extent of acidification on $\delta^{13} \mathrm{C}$ tends to be small. For example, Ventura and Jeppesen (2010) found that the mean shift in $\delta^{13} \mathrm{C}$ in six freshwater fishes (including four fishes of the Cyprinidae) following acid treatment was $0.18 \pm 0.12 \%$. They concluded that acidification of scales is generally biologically irrelevant unless specific questions are being asked in relation to the stable isotopic content of inorganic carbon (Syväranta et al., 2008; Ventura \& Jeppesen, 2010).

All of the stable isotope samples were then oven dried at $60^{\circ} \mathrm{C}$ to constant mass, ground to powder, weighed precisely to $\sim 1000 \mu \mathrm{g}$ in tin capsules and 
analysed on a Thermo Delta $\mathrm{V}$ isotope ratio mass spectrometer (Thermo Scientific, USA), interfaced to a NC2500 elemental analyser (CE Elantach Inc., USA). Accuracy verification was against a range of international reference materials, including air and Vienna Pee Dee Belemnite (International Atomic Energy Agency, Vienna, Austria). Accuracy and precision of sample runs were tested for every 10 samples using a standard mink sample to compensate for possible machine drift and quality control. Overall standard deviation was $0.11 \%$ for $\delta^{15} \mathrm{~N}$ and $0.09 \%$ or $\delta^{13} \mathrm{C}$. Linearity correction was completed to account for differences in peak amplitudes between sample and reference gases $\left(\mathrm{N}_{2}\right.$ or $\left.\mathrm{CO}_{2}\right)$; analytical precision of the $\delta^{15} \mathrm{~N}$ and $\delta^{13} \mathrm{C}$ sample runs was 0.42 and $0.15 \%$, respectively. For both experiments, the stable isotope data for each species and tissue were checked for $\mathrm{C}: \mathrm{N}$ ratios and where these were considered high then mathematical correction for lipid was applied to the $\delta^{13} \mathrm{C}$ data. As there were no species-specific mathematic normalization equations available for the fishes, then three general models were initially considered. The Post et al. (2007) model predicts $\delta^{13} \mathrm{C}$ values from $-3.32+0.99 \times \mathrm{C}: \mathrm{N}$. The Kiljunen et al. (2006) model predicts the lipid-corrected $\delta^{13} \mathrm{C}$ from $\delta^{13} \mathrm{C}+D \times(I+(3.90 /(1+287 / L)))$, where $\delta^{13} \mathrm{C}$ is the original $\delta$ value, $D$ is 7.018 , the difference in carbon isotopic composition between protein and lipid, $I$ is a constant (0.048) and $L$ is the percentage lipid in the sample, estimated from $20.54+7.24 \times \mathrm{C}: \mathrm{N}$ (Post et al. 2007). The Fry (2002) model predicted lipid-free $\delta$ values from $\delta^{13} \mathrm{C}+6-(22.2 / \mathrm{C}: \mathrm{N})$, where $\delta^{13} \mathrm{C}$ is the measured value. The regression relationship between the measured and lipid-free values was tested and the normalization equation with the best fitting model according to the lowest AIC value was selected for subsequent use in analyses. This was the Kiljunen et al. (2006) model (Table S2). As Barnes et al. (2007) identified that elevated C:N ratios in D. labrax were associated with elevated fish condition, then where $\mathrm{C}: \mathrm{N}$ ratios were excessively high for some individuals within a dataset (e.g. $>10 ; c f$. Results), then these data were tested using linear regression against the condition factor $(K)$ of the fishes. $K$ was determined from $L /$ $W^{3}$, where $L$ and $W$ were the values at the conclusion of the experiment.
Analyses of the influence of temperature on $\Delta^{13} \mathrm{C}$ and $\Delta^{15} \mathrm{~N}$

Following stable isotope analysis and lipid correction, the mean $\delta^{13} \mathrm{C}$ and $\delta^{15} \mathrm{~N}$ data of each single food item were subtracted from the $\delta^{13} \mathrm{C}$ and $\delta^{15} \mathrm{~N}$ data of each individual fish to provide individual estimates of $\Delta^{13} \mathrm{C}$ and $\Delta^{15} \mathrm{~N}$. For each fish species and tissue, these discrimination factors were then tested for the significance of their differences between 18 and $23^{\circ} \mathrm{C}$ using generalized linear models (GLMs). For each tissue, the dependent variable was either the $\Delta^{13} \mathrm{C}$ (using both the original and lipid-free values) or $\Delta^{15} \mathrm{~N}$ (no corrections required), the independent variable was temperature and the covariate was length increment (as a proxy of food ration). The significance of differences in $\Delta^{13} \mathrm{C}$ or $\Delta^{15} \mathrm{~N}$ between the temperatures according to tissue type and species was determined by linearly independent pairwise comparisons (with Bonferroni adjustments for multiple comparisons) of the estimated marginal means (i.e. mean $\Delta$ adjusted for the effect of length increment).

Analyses of the influence of diet composition on $\Delta^{13} \mathrm{C}$ and $\Delta^{15} \mathrm{~N}$

The initial step was to estimate the $\mathrm{C}: \mathrm{N}$ ratio of each diet by weighting the $\mathrm{C}: \mathrm{N}$ ratio of each dietary item against their diet proportion (cf. Table 1) and then totaling these values per diet. Estimates of $\Delta^{13} \mathrm{C}$ and $\Delta^{15} \mathrm{~N}$ per tissue across the four diets for $C$. auratus were then derived using the methodology outlined by Hussey et al. (2010). The initial step was to determine the isotopic composition of each total diet over the 100-day experimental period according to their proportional composition of dietary items (Table 1). As the items comprising each diet varied in their proximate composition (i.e. the proportion of bulk $\mathrm{N}$ and $\mathrm{C}$ ), then the fractional contributions of $\mathrm{N}, \mathrm{C}$ and biomass (i.e. the proportional contribution to the total mass of the diet; B) were adjusted to equal 1 (Hussey et al., 2010). Thus, if $f_{\mathrm{X}, \mathrm{B}}, f_{\mathrm{Y}, \mathrm{B}}$ and $f_{\mathrm{Z}, \mathrm{B}}$ equal the fractions of assimilated biomass of prey items $X, Y$ and $\mathrm{Z}$ and $f_{\mathrm{X}, \mathrm{N}}, f_{\mathrm{Y}, \mathrm{N}}, f_{\mathrm{Z}, \mathrm{N}}, f_{\mathrm{X}, \mathrm{C}}, f_{\mathrm{Y}, \mathrm{C}}$ and $f_{\mathrm{Z}, \mathrm{C}}$ represent the fractions of assimilated $\mathrm{N}$ and $\mathrm{C}$ of individual prey items, respectively, then $f_{\mathrm{X} ; \mathrm{B}}+f_{\mathrm{Y} ; \mathrm{B}}+f_{\mathrm{Z} ; \mathrm{B}}=1$; $f_{\mathrm{X} ; \mathrm{N}}+f_{\mathrm{Y} ; \mathrm{N}}+f_{\mathrm{Z} ; \mathrm{N}}=1$ and $f_{\mathrm{X} ; \mathrm{C}}+f_{\mathrm{Y} ; \mathrm{C}}+f_{\mathrm{Z} ; \mathrm{C}}=1$. It was then assumed that the contribution of a dietary item to the fish was proportional to the assimilated 
biomass multiplied by the elemental ( $\mathrm{N}$ and $\mathrm{C}$ ) concentration of that prey (Phillips \& Koch 2002; Hussey et al., 2010). Correspondingly, if $[\mathrm{N}]_{\mathrm{X}},[\mathrm{N}]_{\mathrm{Y}}$, $[\mathrm{N}]_{Z},[\mathrm{C}]_{\mathrm{X}},[\mathrm{C}]_{\mathrm{Y}}$ and $[\mathrm{C}]_{\mathrm{Z}}$ equal the contributions of $\mathrm{N}$ and $\mathrm{C}$ in prey items $\mathrm{X}, \mathrm{Y}$ and $\mathrm{Z}$, then for nitrogen

$f_{\mathrm{X}, \mathrm{N}}=f_{\mathrm{X}, \mathrm{B}}[\mathrm{N}] / f_{\mathrm{X}, \mathrm{B}}[\mathrm{N}]_{\mathrm{X}}+f_{\mathrm{Y}, \mathrm{B}}[\mathrm{N}]_{\mathrm{Y}}+f_{\mathrm{Z}, \mathrm{B}}[\mathrm{N}]_{\mathrm{Z}}$

$f_{\mathrm{Y}, \mathrm{N}}=f_{\mathrm{X}, \mathrm{B}}[\mathrm{N}] / f_{\mathrm{X}, \mathrm{B}}[\mathrm{N}]_{\mathrm{X}}+f_{\mathrm{Y}, \mathrm{B}}[\mathrm{N}]_{\mathrm{Y}}+f_{\mathrm{Z}, \mathrm{B}}[\mathrm{N}]_{\mathrm{Z}}$

$f_{\mathrm{Z}, \mathrm{N}}=f_{\mathrm{X}, \mathrm{B}}[\mathrm{N}] / f_{\mathrm{X}, \mathrm{B}}[\mathrm{N}]_{\mathrm{X}}+f_{\mathrm{Y}, \mathrm{B}}[\mathrm{N}]_{\mathrm{Y}}+f_{\mathrm{Z}, \mathrm{B}}[\mathrm{N}]_{\mathrm{Z}}$

Repeating this for carbon, i.e. $f_{\mathrm{X}, \mathrm{C}}, f_{\mathrm{Y}, \mathrm{C}}, f_{\mathrm{Z}, \mathrm{C}}$, substituted $[\mathrm{C}]_{\mathrm{X}},[\mathrm{C}]_{\mathrm{Y}}$ and $[\mathrm{C}]_{\mathrm{Z}}$ for $[\mathrm{N}]_{\mathrm{X}},[\mathrm{N}]_{\mathrm{Y}}$ and $[\mathrm{N}]_{\mathrm{Z}}$ (Hussey et al., 2010). The isotopic signatures $\left(\delta^{15} \mathrm{~N}\right.$ and $\left.\delta^{13} \mathrm{C}\right)$ of each total diet $\left(\delta^{15} \mathrm{~N}_{\text {Diet }}^{\mathrm{T}}\right.$ and $\delta^{13} \mathrm{C}_{\text {Diet }}^{\mathrm{T}}$ ), as corrected for $\mathrm{C}$ and $\mathrm{N}$ concentration, were then estimated from

$\delta^{15} \mathrm{~N}_{\text {Diet }}^{\mathrm{T}}=f_{\mathrm{X}, \mathrm{N}} \delta^{15} \mathrm{~N}_{\mathrm{X}}+f_{\mathrm{Y}, \mathrm{N}} \delta^{15} \mathrm{~N}_{\mathrm{Y}}+f_{\mathrm{Z}, \mathrm{N}} \delta^{15} \mathrm{~N}_{\mathrm{Z}}$

$\delta^{13} \mathrm{C}_{\text {Diet }}^{\mathrm{T}}=f_{\mathrm{X}, \mathrm{C}} \delta^{13} \mathrm{C}_{\mathrm{X}}+f_{\mathrm{Y}, \mathrm{C}} \delta^{13} \mathrm{CY}+f_{\mathrm{Z}, \mathrm{C}} \delta^{13} \mathrm{C}_{\mathrm{Z}}$

where $\delta^{15} \mathrm{~N}_{\mathrm{X}}, \delta^{15} \mathrm{~N}_{\mathrm{Y}}, \delta^{15} \mathrm{~N}_{\mathrm{Z}}, \delta^{13} \mathrm{C}_{\mathrm{X}}, \delta^{13} \mathrm{C}_{\mathrm{Y}}$ and $\delta^{13} \mathrm{C}_{\mathrm{Z}}$ are the $\delta^{15} \mathrm{~N}$ and $\delta^{13} \mathrm{C}$ values of prey items $\mathrm{X}, \mathrm{Y}$ and $\mathrm{Z}$, respectively (Hussey et al., 2010).

For each diet, the discrimination factors of $\Delta^{13} \mathrm{C}$ and $\Delta^{15} \mathrm{~N}$ for each individual fish were determined for each tissue from

$$
\begin{aligned}
& \Delta^{15} \mathrm{~N}=\delta^{15} \mathrm{~N}_{\text {tissue }}-\delta^{15} \mathrm{~N}_{\text {Diet }}^{\mathrm{T}} \\
& \Delta^{13} \mathrm{C}=\delta^{13} \mathrm{C}_{\text {tissue }}-\delta^{13} \mathrm{C}_{\text {Diet }}^{\mathrm{T}}
\end{aligned}
$$

where $\delta^{15} \mathrm{~N}_{\text {tissue }}$ and $\delta^{13} \mathrm{C}_{\text {tissue }}$ are the nitrogen and carbon isotope values of the tissue as derived from the stable isotope analysis, respectively. These discrimination factors were then presented as mean $\pm 95 \%$ confidence limits. The significance of their differences between D1 (based on natural prey items) and the other diets (based on natural prey items and formulated feeds) were tested using generalized linear models, where the dependent variable was $\Delta^{13} \mathrm{C}$ or $\Delta^{15} \mathrm{~N}$ and the independent variable was diet, with the significance of differences between diets determined from linearly independent pairwise comparisons of the estimated marginal means, with Bonferroni adjustment for multiple comparisons. Initial models used the length increments of the fish as the covariate, but these were removed from all final models due to their effects being non-significant (cf. Results). The discrimination factors were then compared against the weighted values of the C:N ratios per diet.

Throughout the Results, variation around the mean represents $95 \%$ confidence limits unless otherwise stated. Statistics were completed in SPSS v.22 (IBM, 2013). All experimental procedures and ethical regulations were completed under UK Home Office project licence PPL30/3094 that was granted following ethical review at the host institution.

\section{Results}

Temperature effects on stable isotope discrimination factors

Across the 150-day period, the length and mass of all fishes increased (Supplementary information: Table S1). The length and weight increments produced by each species were not significantly different between the two temperatures (GLM: $C$. carpio length: Wald $\chi^{2}=0.94, P=0.64$, weight: Wald $\chi^{2}=0.89, \quad P=0.48 ; \quad C$. auratus length: Wald $\chi^{2}=0.74, \quad P=0.59$, weight: Wald $\chi^{2}=0.79$, $P=0.51 ;$ S. cephalus length: Wald $\chi^{2}=1.43$, $P=0.15$, weight: Wald $\chi^{2}=1.14, \quad P=0.24$ ) (Table S1).

The GLMs testing differences between the C:N ratios of each species by tissue and temperature were significant (C. carpio: Wald $\chi^{2}=30.67, P<0.01 ; C$. auratus: Wald $\chi^{2}=107.66, \mathrm{P}<0.01 ;$ S. cephalus: Wald $\chi^{2}=10.95, P=0.05$ ). There was a pattern of $\mathrm{C}: \mathrm{N}$ ratios being generally higher at 23 than $18^{\circ} \mathrm{C}$ (Fig. 1). However, pairwise comparisons in the models revealed that the significant differences were between the tissues for each species rather than between temperatures. For example, $\mathrm{C}: \mathrm{N}$ ratios of $C$. carpio muscle were significantly higher than those of fin and scale tissue $(P<0.05)$ and, irrespective of temperature and species, scale $\mathrm{C}: \mathrm{N}$ ratios were significantly lower than those of muscle and fin tissue $(P<0.05)$ (Fig. 1). Mean $\mathrm{C}: \mathrm{N}$ ratio of muscle was $\geq 4.0$ for all species, with the highest mean ratio being $5.88 \pm 1.91 \%$ for muscle of $C$. carpio at $23^{\circ} \mathrm{C}$ (Fig. 1). Of these eight C. carpio at $23^{\circ} \mathrm{C}$, two had ratios $>10.0$ and the relationship between $\mathrm{C}: \mathrm{N}$ ratio and fish condition factor was positive and significant 

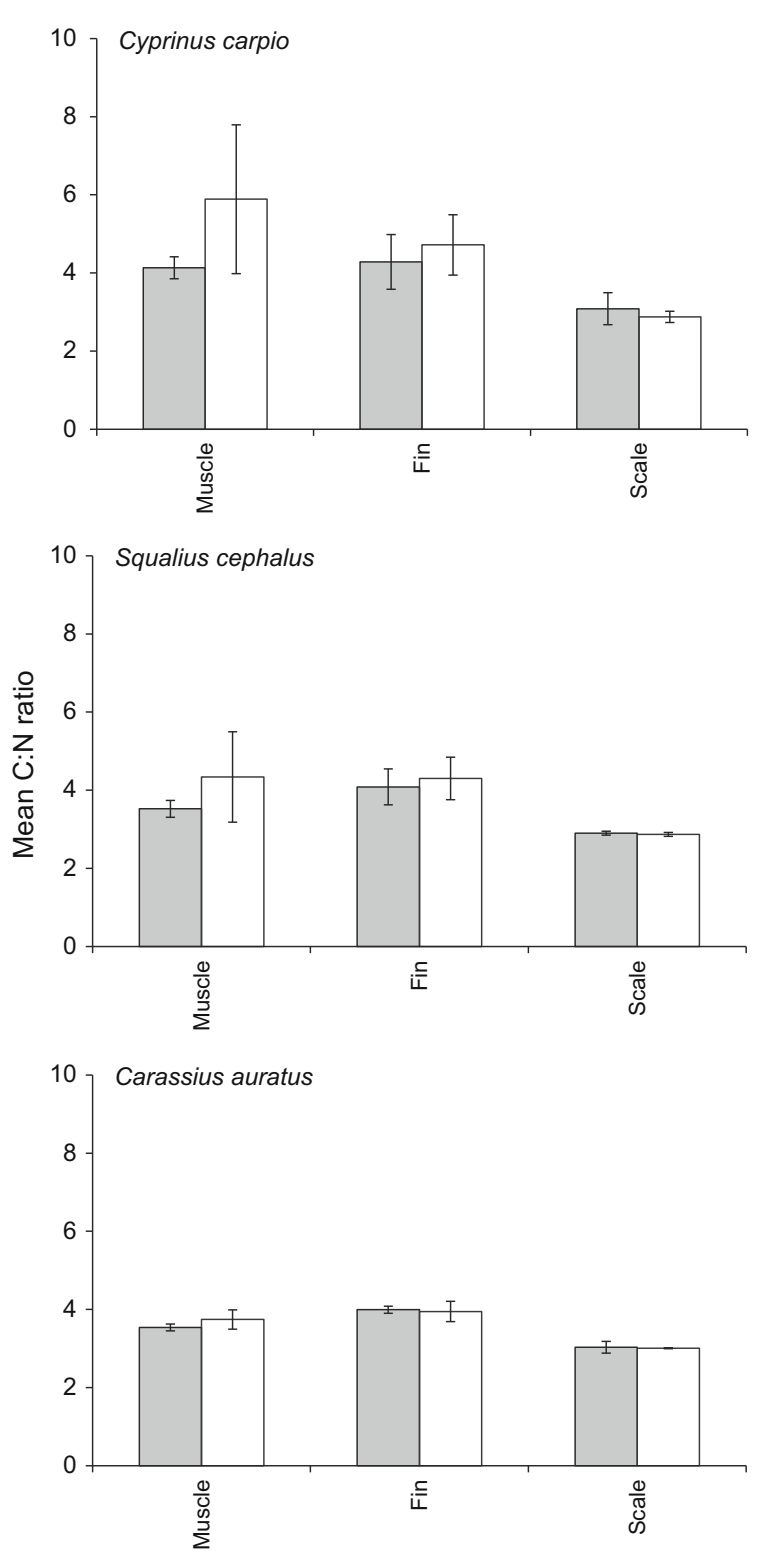

Tissue

Fig. 1 Ratios of carbon:nitrogen per species and tissue according to temperature $\left(18^{\circ} \mathrm{C}\right.$ : grey bars; $23^{\circ} \mathrm{C}$ : clear bars $)$. Error around the mean represents $95 \%$ confidence limits

(linear regression: $\quad R^{2}=0.70, \quad F_{1,6}=13.99$, $P=0.01)$. As a result of these $\mathrm{C}: \mathrm{N}$ ratios, mathematical lipid normalization was applied to the $\delta^{13} \mathrm{C}$ data using the Kiljunen et al. (2006) method (Table S2).

Among the three fishes and their tissues, mathematical normalization for lipid resulted in increased fractionation values for $\Delta^{13} \mathrm{C}$ (Table 2). Where there was a significant difference between the temperatures in $\Delta^{13} \mathrm{C}$ and $\Delta^{15} \mathrm{~N}$, it was always higher at $23^{\circ} \mathrm{C}$ than at $18^{\circ} \mathrm{C}$ (Tables 2, 3, S3). For C. carpio, the general pattern was of lipid-normalized $\Delta^{13} \mathrm{C}$ being significantly higher for each tissue at $23^{\circ} \mathrm{C}$, with mean differences between 0.35 and $0.73 \%$ (Table 2), whilst for $S$. cephalus the only significant difference between the temperatures was for lipid-normalized $\Delta^{13} \mathrm{C}$ in dorsal muscle (Table 3). For C. auratus, $\Delta^{15} \mathrm{~N}$ was significantly higher at 23 than $18^{\circ} \mathrm{C}$ in each tissue, but only for fin and scales for the original $\Delta^{13} \mathrm{C}$ values and only scales for lipid-free $\Delta^{13} \mathrm{C}$ (Table 2). Regarding the effect of length as a proxy of food ration size, it only had a significant effect on discrimination in $C$. carpio muscle (Tables 2, 3).

Effects of diet composition on stable isotope discrimination factors

For each diet, their food items by proportion and the corresponding stable isotope data were used in Eqs. 15 to estimate $\delta^{13} \mathrm{C}_{\text {diet }}^{\mathrm{T}}$ and $\delta^{15} \mathrm{~N}_{\text {diet }}^{\mathrm{T}}$ (Table 1, S4), with these used in Eqs. 6 and 7 to estimate $\Delta^{13} \mathrm{C}$ and $\Delta^{15} \mathrm{~N}$ for each diet and tissue, respectively (Tables 1, 4, 5). For each tissue, $\Delta{ }^{13} \mathrm{C}$ was always the lowest in Diet D1 that comprised only natural prey items; it was the highest in D3, based on 'WG' pellets (Tables 1, 5, S4). For $\Delta^{15} \mathrm{~N}$, the lowest values were in D1 and always highest in D3. For each tissue and isotopic discrimination factor, there were significant differences between the diets, with this being most apparent between D1 (100\% natural diet) and D3 (70\% WG pellet), where $\Delta^{13} \mathrm{C}$ and $\Delta^{15} \mathrm{~N}$ were significantly different for each tissue (Tables 4, 5). Across the diets, there was no overall pattern between the weighted C:N ratios and $\Delta^{13} \mathrm{C}$ and $\Delta^{15} \mathrm{~N}$ (Fig. 2).

\section{Discussion}

Across the experiments, there was a predictable pattern in the discrimination factors between the tissues, with factors for muscle being relatively low compared with fin tissue and scales. This predictable nature of the differences in discrimination factors across the tissues was consistent with the first hypothesis and so supports the use of fin tissue and scales as non-lethal substitutes for dorsal muscle in fish isotope studies. For fin and scales, differences in discrimination were relatively minor, with some variation according to species and 
Table 2 Outputs of generalized linear models testing the effect of the two temperatures on the discrimination factors $(\Delta)$ of the original and mathematical normalized values ('lipid free'; Kiljunen et al., 2006) of ${ }^{13} \mathrm{C}$ according to tissue type for each species and where the covariate in models was the length increment produced by individual fish over the experimental period

\begin{tabular}{|c|c|c|c|}
\hline $\begin{array}{l}\text { Discrimination } \\
\text { factor }\end{array}$ & Tissue & Wald $\chi^{2}, P$ & $\begin{array}{l}\text { Significance of length increment (as } \\
\text { covariate) }\end{array}$ \\
\hline
\end{tabular}

Mean discrimination factor by temperature (as estimated marginal mean controlled for the effect of length increment)

\begin{tabular}{|c|c|c|c|c|c|}
\hline & & & & \\
\hline & & & & $18^{\circ} \mathrm{C}$ & $23^{\circ} \mathrm{C}$ \\
\hline \multicolumn{6}{|c|}{ Cyprinus carpio } \\
\hline \multirow[t]{3}{*}{$\begin{array}{l}\text { Original } \\
\Delta^{13} \mathrm{C}(\% 0)\end{array}$} & $\begin{array}{l}\text { Dorsal } \\
\text { muscle }\end{array}$ & $0.82 ; P=0.37$ & 0.99 & $1.15 \pm 0.48$ & $0.85 \pm 0.45$ \\
\hline & Fin & $0.33 ; P=0.57$ & 0.52 & $2.03 \pm 0.52$ & $2.24 \pm 0.48$ \\
\hline & Scale & $6.40, P=0.01$ & 0.64 & $3.15 \pm 0.45$ & $4.02 \pm 0.45^{*}$ \\
\hline \multirow[t]{3}{*}{$\begin{array}{l}\text { Lipid-free } \\
\Delta^{13} \mathrm{C}(\%)\end{array}$} & $\begin{array}{l}\text { Dorsal } \\
\text { muscle }\end{array}$ & $9.56, P<0.01$ & 0.04 & $2.36 \pm 0.15$ & $2.70 \pm 0.16^{*}$ \\
\hline & Fin & $7.83 ; P<0.01$ & 0.15 & $3.31 \pm 0.21$ & $3.86 \pm 0.22 *$ \\
\hline & Scale & $9.45, P<0.01$ & 0.58 & $3.65 \pm 0.34$ & $4.38 \pm 0.31 *$ \\
\hline \multicolumn{6}{|c|}{ Squalius cephalus } \\
\hline \multirow[t]{3}{*}{$\begin{array}{l}\text { Original } \\
\Delta^{13} \mathrm{C}(\%)\end{array}$} & $\begin{array}{l}\text { Dorsal } \\
\text { muscle }\end{array}$ & $0.19 ; P=0.56$ & 0.56 & $1.33 \pm 0.37$ & $1.19 \pm 0.49$ \\
\hline & Fin & $1.36 ; P=0.24$ & 0.10 & $3.32 \pm 0.32$ & $3.63 \pm 0.31$ \\
\hline & Scale & $1.49, P=0.22$ & 0.10 & $3.28 \pm 0.25$ & $3.54 \pm 0.33$ \\
\hline \multirow[t]{3}{*}{$\begin{array}{l}\text { Lipid-free } \\
\Delta^{13} \mathrm{C}(\% \mathrm{)})\end{array}$} & $\begin{array}{l}\text { Dorsal } \\
\text { muscle }\end{array}$ & $\begin{array}{l}29.88 \\
\quad P<0.01\end{array}$ & 0.07 & $2.13 \pm 0.10$ & $2.58 \pm 0.13^{*}$ \\
\hline & Fin & $1.18 ; P=0.28$ & 0.41 & $4.51 \pm 0.51$ & $4.98 \pm 0.68$ \\
\hline & Scale & $1.41, P=0.24$ & 0.08 & $3.67 \pm 0.31$ & $3.90 \pm 0.37$ \\
\hline \multicolumn{6}{|c|}{ Carassius auratus } \\
\hline \multirow[t]{3}{*}{$\begin{array}{l}\text { Original } \\
\Delta^{13} \mathrm{C}(\%)\end{array}$} & $\begin{array}{l}\text { Dorsal } \\
\text { muscle }\end{array}$ & $0.32, P=0.25$ & 0.40 & $1.82 \pm 0.18$ & $1.64 \pm 0.19$ \\
\hline & Fin & $3.82, P=0.05$ & 0.64 & $3.49 \pm 0.28$ & $3.91 \pm 0.26^{*}$ \\
\hline & Scale & $6.62, P=0.01$ & 0.07 & $3.50 \pm 0.29$ & $4.07 \pm 0.29 *$ \\
\hline \multirow[t]{3}{*}{$\begin{array}{l}\text { Lipid-free } \\
\Delta^{13} \mathrm{C}(\%)\end{array}$} & $\begin{array}{l}\text { Dorsal } \\
\text { muscle }\end{array}$ & $0.12, P=0.73$ & 0.06 & $2.62 \pm 0.12$ & $2.65 \pm 0.11$ \\
\hline & Fin & $2.48, P=0.12$ & 0.65 & $4.62 \pm 0.33$ & $5.01 \pm 0.33$ \\
\hline & Scale & $7.56, P<0.01$ & 0.09 & $3.98 \pm 0.26$ & $4.51 \pm 0.26^{*}$ \\
\hline
\end{tabular}

Error around the mean represents $95 \%$ confidence limits

* Difference in $\Delta$ between the temperatures significant at $P<0.05$

diet. Where there were significant effects of temperature on $\Delta^{13} \mathrm{C}$, the discrimination factor was always elevated at the higher temperature for both the original and lipid-normalized values. These results were in line with the previous studies of Power et al. (2003) and Barnes et al. (2007) that have demonstrated similar effects of temperature on $\Delta^{13} \mathrm{C}$ and were also consistent with the second hypothesis. However, lower discrimination in $\Delta^{15} \mathrm{~N}$ was not apparent at the higher temperature, contrary to prediction and Barnes et al. (2007) who worked on D. labrax. In the diet experiment, there were significant differences in discrimination factors between the diets, with this being consistent with the third hypothesis. The mechanisms underlying these differences in the discrimination factors across the two experiments potentially relate to 
Table 3 Outputs of generalized linear models testing the effect of the two temperatures on the discrimination factors $(\Delta)$ of ${ }^{15} \mathrm{~N}$ according to tissue type and where the covariate in models was the length increment produced by individual fish over the experimental period

\begin{tabular}{|c|c|c|c|c|c|}
\hline \multirow[t]{2}{*}{ Species } & \multirow[t]{2}{*}{ Tissue } & \multirow[t]{2}{*}{ Wald $\chi^{2}, P$} & \multirow[t]{2}{*}{ Significance of length increment (as covariate) } & \multicolumn{2}{|c|}{$\begin{array}{l}\text { Mean discrimination factor } \\
\text { by temperature (as } \\
\text { estimated marginal mean } \\
\text { controlled for the effect of } \\
\text { length increment) }\end{array}$} \\
\hline & & & & $18^{\circ} \mathrm{C}$ & $23^{\circ} \mathrm{C}$ \\
\hline \multirow[t]{3}{*}{ Cyprinus carpio } & $\begin{array}{l}\text { Dorsal } \\
\text { muscle }\end{array}$ & $1.93 ; P=0.17$ & $<0.01$ & $0.98 \pm 0.18$ & $0.81 \pm 0.16$ \\
\hline & Fin & $1.24 ; P=0.17$ & 0.08 & $1.22 \pm 0.16$ & $1.24 \pm 0.17$ \\
\hline & Scale & $6.24 ; P=0.01$ & 0.04 & $1.09 \pm 0.18$ & $1.41 \pm 0.17 *$ \\
\hline \multirow[t]{3}{*}{$\begin{array}{l}\text { Squalius } \\
\quad \text { cephalus }\end{array}$} & $\begin{array}{l}\text { Dorsal } \\
\text { muscle }\end{array}$ & $1.21, P=0.27$ & 0.32 & $2.03 \pm 0.12$ & $1.92 \pm 0.16$ \\
\hline & Fin & $0.81, P=0.37$ & 0.21 & $2.27 \pm 0.17$ & $2.39 \pm 0.22$ \\
\hline & Scale & $1.31, P=0.25$ & 0.27 & $1.66 \pm 0.19$ & $1.47 \pm 0.26$ \\
\hline \multirow[t]{3}{*}{$\begin{array}{c}\text { Carassius } \\
\text { auratus }\end{array}$} & $\begin{array}{l}\text { Dorsal } \\
\text { muscle }\end{array}$ & $5.30, P=0.02$ & 0.09 & $1.00 \pm 0.21$ & $1.37 \pm 0.21^{*}$ \\
\hline & Fin & $\begin{array}{l}13.47 \\
\quad P<0.01\end{array}$ & 0.09 & $1.08 \pm 0.20$ & $1.62 \pm 0.20^{*}$ \\
\hline & Scale & $3.78, P=0.05$ & 0.77 & $0.65 \pm 0.21$ & $0.98 \pm 0.21^{*}$ \\
\hline
\end{tabular}

Error around the mean represents $95 \%$ confidence limits

*Difference in $\Delta$ between the temperatures significant at $P<0.05$

differences in $\mathrm{C}: \mathrm{N}$ ratios and differences in the protein quality and quantity between the diets, with the latter enabling testing of the fourth hypothesis. These mechanisms are discussed in turn.

The ratios of $\mathrm{C}: \mathrm{N}$ have been used as a surrogate of the quantity of fat reserve in that analysed tissue (Barnes et al., 2007), although the relationship between the C:N and lipid concentration of a tissue is not always predictable (Fagan et al., 2011). Nevertheless, previous stable isotope studies tend to suggest that where $\mathrm{C}: \mathrm{N}$ ratios are relatively high (e.g. $>3.5 \%$ ) then lipid normalization for $\delta^{13} \mathrm{C}$ and thus $\Delta^{13} \mathrm{C}$ is necessary (Kiljunen et al., 2006; Post et al., 2007). In the temperature experiment, this was only an issue for muscle samples, where $\mathrm{C}: \mathrm{N}$ ratios always exceeded 3.5. In the temperature experiment, the greatest variability in $\mathrm{C}: \mathrm{N}$ ratios was in $C$. carpio muscle at $23^{\circ} \mathrm{C}$, where the ratios ranged between 3.51 and 10.07 for individual fish. These $\mathrm{C}: \mathrm{N}$ ratios had a positive and significant relationship with fish condition, suggesting that the condition could account for some of the variability in $\Delta^{13} \mathrm{C}$ detected in the discrimination factors between the temperatures. This was also detected in D. labrax by Barnes et al. (2007), although the physiological driver of this was not explored. Similarly, in the diet experiment, the highest C:N ratios were generally in muscle and were also in the diets that involved formulated feeds (D2 to D4). The lowest ratio for muscle was from Diet D1 that was based entirely on natural prey items and thus could have resulted in relatively low quantities of fat being reserved. As mathematical lipid correction was not applied in the diet experiment, then the elevated $\Delta \delta^{13} \mathrm{C}$ in diets D2 to D4 might at least partially relate to their tissues having higher fat levels.

Notwithstanding some of the differences in $\mathrm{C}: \mathrm{N}$ ratios across the experiments, these do not account for all of the differences apparent in the muscle discrimination factors detected across the four diets. Moreover, there were also differences in discrimination factors apparent in fin and scale tissue in which the $\mathrm{C}: \mathrm{N}$ ratios were consistently lower and usually $<3.5$. Correspondingly, the variability in both discrimination factors in the diet experiment was more likely to 


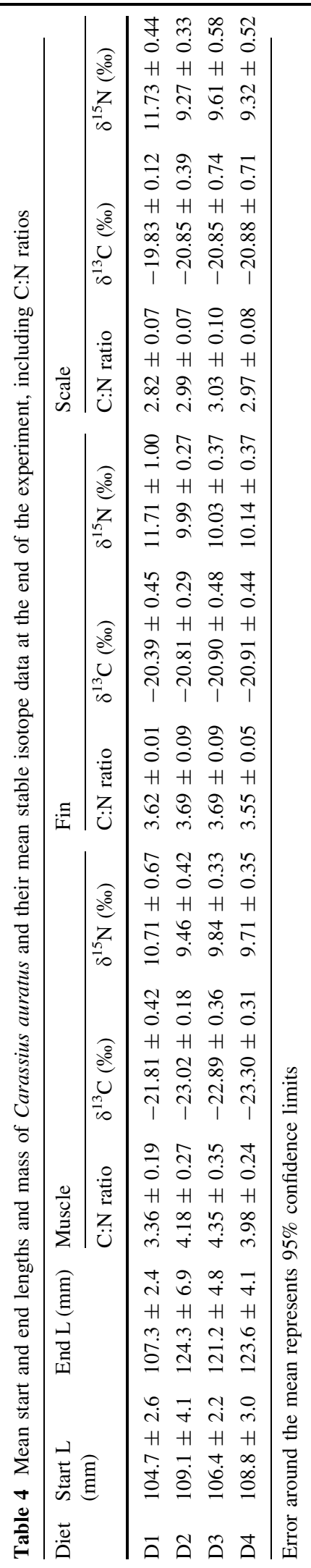


Table 5 Discrimination factors $(\Delta)$ of (A) $\delta^{13} \mathrm{C}$ and (B) $\delta^{15} \mathrm{~N}$ of Carassius auratus per tissue type for each diet, and the outputs of the GLM testing for the significance of differences in $\Delta^{13} \mathrm{C}$ and $\Delta^{15} \mathrm{~N}$, where $*$ indicates that the difference between $\Delta \mathrm{D} 1$ and $\Delta D x$ is significant at $P \leq 0.05$ according to pairwise comparisons with Bonferroni adjustment for multiple comparisons

\begin{tabular}{lllllll}
\hline Stable isotope & Tissue & Wald $\chi^{2} ; P$ & $\Delta$ D1 (\%o) & $\Delta$ D2 (\%o) & $\Delta$ D3 (\%o) & $\Delta$ D4 (\%o) \\
\hline (A) $\delta^{13} \mathrm{C}$ & Muscle & $45.75, P<0.01$ & $1.51 \pm 0.40$ & $1.82 \pm 0.19$ & $2.76 \pm 0.38^{*}$ & $1.70 \pm 0.35$ \\
& Fin & $27.42, P<0.01$ & $2.93 \pm 0.42$ & $4.03 \pm 0.32^{*}$ & $4.75 \pm 0.47^{*}$ & $4.09 \pm 0.46^{*}$ \\
& Scale & $11.45, P<0.01$ & $3.49 \pm 0.16$ & $3.99 \pm 0.37$ & $4.79 \pm 0.78$ & $4.12 \pm 0.75$ \\
(B) $\delta^{15} \mathrm{~N}$ & Muscle & $147.46, P<0.01$ & $3.13 \pm 0.69$ & $4.20 \pm 0.41^{*}$ & $5.44 \pm 0.34^{*}$ & $4.39 \pm 0.30^{*}$ \\
& Fin & $101.49, P<0.01$ & $4.13 \pm 1.01$ & $4.73 \pm 0.31$ & $5.64 \pm 0.41$ & $4.93 \pm 0.45$ \\
& Scale & $74.56, P<0.01$ & $4.15 \pm 0.43$ & $4.01 \pm 0.37$ & $5.22 \pm 0.61$ & $4.11 \pm 0.55$ \\
\hline
\end{tabular}

Error around the mean represents $95 \%$ confidence limits
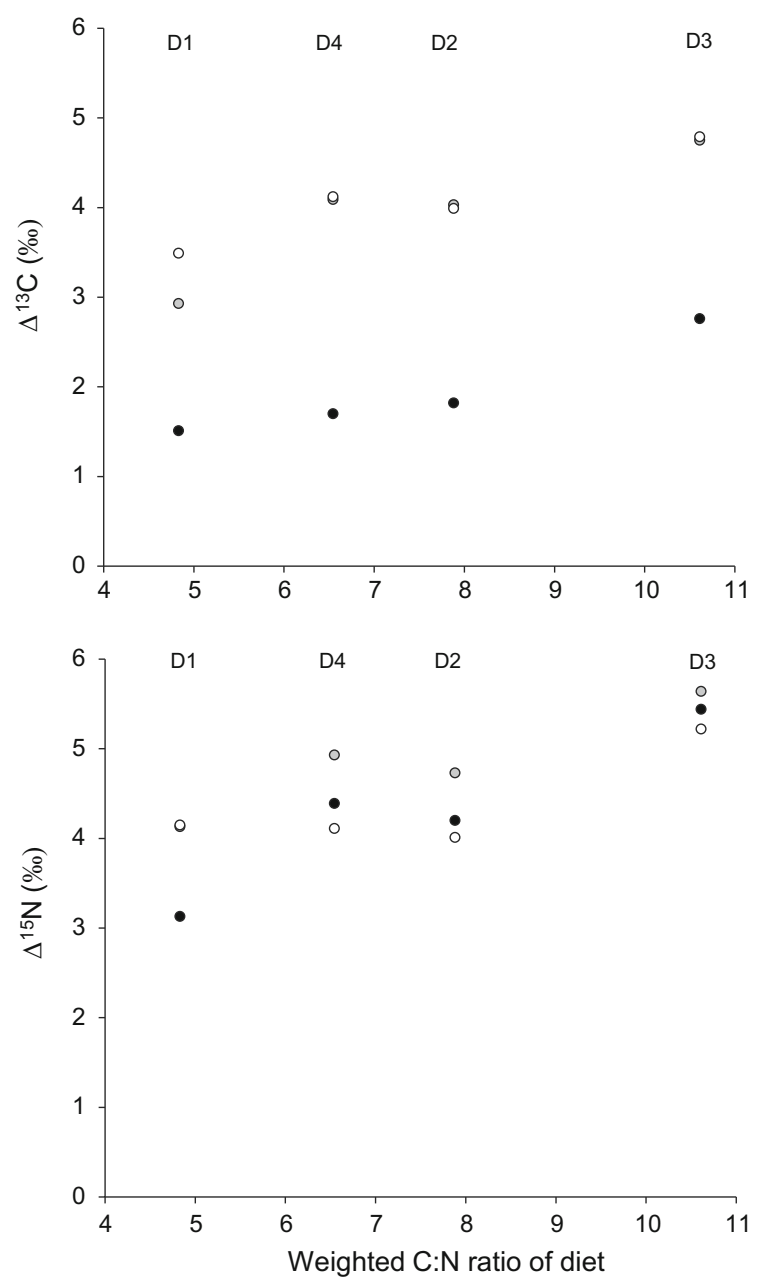

Fig. 2 Weighted carbon:nitrogen ratios per diet versus their mean fractionation factor in C. auratus. Black circle: muscle; grey circle: fin tissue; clear circle: scale. Note that error bars are not provided for brevity relate to the contrasting sources of dietary protein available from each diet (McClelland et al., 2003). The 'protein quality hypothesis' suggests that discrimination in the stable isotopes of consumers and their prey increases as protein quality decreases; as carnivores usually assimilate higher quality protein than herbivores, then discrimination should decrease as trophic level increases (Roth \& Hobson, 2000). In the diet experiment, the lowest $\Delta^{15} \mathrm{~N}$ was in $\mathrm{D} 1$, composed entirely of natural items with very low plant content (approximately 5\% Spirogyra), and then D2 and D4 that both had relatively high contributions of a fishmeal pellet (30 and 70\%, respectively) comprised $45 \%$ fish protein (i.e. a high-quality protein base). In contrast, the highest $\Delta^{15} \mathrm{~N}$ was in Diet D3 that had approximately $85 \%$ of its dietary origin from plant material, including $70 \%$ from the 'WG' pellet that was of relatively low protein content $(20 \%)$. Thus, diets D1, D2 and D4 arguably comprised higher protein quality than D3 and so $\Delta^{15} \mathrm{~N}$ across the four diets at least partially aligned with the protein quality hypothesis. That D3 had the highest $\Delta^{13} \mathrm{C}$ of all diets was generally consistent with Macko et al. (1986), who suggested that as dietary protein decreases, the percentage of nitrogen in the diet decreases and less amino acids are catabolized for energy. This then potentially increases the discrimination factors of protein-poor diets (Macko et al., 1986). As there was no overall pattern between the discrimination factors per diet and their weighted C:N ratio, then there was no support for the 'protein quantity hypothesis' that suggests that the discrimination factors increase as $\mathrm{C}: \mathrm{N}$ ratios decrease (i.e. as dietary nitrogen concentration decreases) (Pearson et al., 2003). 
In other studies across a number of different taxa (e.g. mammals and birds), discrimination factors have also decreased as protein quality has increased, such as through the increase occurring with trophic level (i.e. herbivores to carnivores) (e.g. Robbins et al., 2005). Similar to the results of the dietary experiment here, relationships between discrimination factors and dietary nitrogen quantity and $\mathrm{C}: \mathrm{N}$ ratios were either not significant or contrary to the "protein quantity hypothesis' (Robbins et al., 2005). These results are important as the protein quality of a mixed diet is then dependent on the extent to which the profiles and amounts of essential amino acids in the different prey of an individual food are complementary in meeting that individual's requirements (Robbins et al., 2010). In entirety, these results indicate that using isotopes to estimate assimilated diets is complex, with determination of the appropriate discrimination factors to apply to mixing models requiring further knowledge that covers, for example, the interactions of animal physiology, dietary protein composition and environmental variables such as temperature. These results also indicate that, currently, there remains some uncertainty over the discrimination factors that should be applied to mixing models, especially for those species for which taxon-specific factors have yet to be determined (Phillips et al., 2014). Approaches, such as those recently suggested by Bastos et al. (2017) that utilize food source-specific discrimination factors, thus warrant further investigation.

The diet-tissue discrimination factors reported here across three species and a range of conditions contribute to knowledge on how the environment and diet of fishes affect their stable isotope data. For example, for Diet D1, based entirely on natural prey, the mean muscle discrimination factors of 1.51 and $3.13 \%$ for $\Delta^{13} \mathrm{C}$ and $\Delta^{15} \mathrm{~N}$, respectively, were not too dissimilar to the more general discrimination factors that are often used where species-specific data are missing (e.g. $\quad \delta^{13} \mathrm{C}: \quad 0.39 \pm 1.3 \% ; \quad \delta^{15} \mathrm{~N}$ : $3.4 \pm 0.98 \%$; Minagawa \& Wada, 1984; Post, 2002). However, when formulated feeds were present in fish diet (D2 to D4), then these increased their discrimination factors compared with D1, especially in D3 where pellets were based on plant material with relatively low protein content. The relatively high discrimination factors recorded in diets with higher plant content were also consistent with omnivore studies in the wild (e.g. Bastos et al., 2017). These elevated discrimination factors were also consistent with Mill et al. (2007), who recorded $\Delta^{15} \mathrm{~N}$ in herbivorous fishes to $5.25 \%$. Correspondingly, the diet experiment suggests that when the trophic ecology of omnivorous fishes is studied and actual or literature-based stomach contents data on the focal species suggests there is a high proportion of plant material in their diet then relatively high discrimination factors should be applied in the analyses of their stable isotope data, such as in mixing models.

It is also important to note that trophic step discrimination factors determined in controlled experimental settings might not necessarily reflect those that develop in wild conditions (Busst \& Britton, 2016). Therefore, such experiments could benefit from further validation of discrimination factors in experiments conducted in more natural conditions (Barnes et al., 2007). A potential issue with the temperature experiment conducted here was that whilst 100 days was assumed to be of sufficient length for isotopic equilibrium to be reached, Thomas and Crowther (2015) suggest that this duration might have only enabled approximately 3.5 isotopic half-lives to be completed. Thus, the tissues might not have been at isotopic equilibrium at the end of the 100 days (Thomas \& Crowther, 2015). Notwithstanding, the duration of fish growth seasons for cyprinid species in most temperate regions will rarely comprise more than 100 consecutive days where water temperatures exceed $18^{\circ} \mathrm{C}$ (Britton, 2007). Consequently, the extent of diet-tissue discrimination in the experiment might be similar to that expected in the wild during a temperate fish growth season in which individuals switch diet, such as due to an ontogenetic shift. In contrast, the duration of the temperature experiment of Barnes et al. (2007) was 600 days, where D. labrax were held at 11 and $16^{\circ} \mathrm{C}$. Whilst this duration could be realistic for marine environments, it is not for temperate freshwaters, as per this study.

In addition to concerns over experiment length, the use of formulated feeds in diets D2-D4 might also suggest that the resultant discrimination factors are not appropriate for use in wild studies. However, these formulated feeds are increasingly present as strong trophic subsidies in many European freshwaters, primarily through their use as baits by anglers in both lentic and lotic habitats (Jackson et al., 2013; Bašić et al., 2015; Gutmann-Roberts et al., 2017), but also from aquaculture (e.g. Grey et al., 2004). For example, 
in lowland rivers in England, anglers introduce large quantities of fishmeal pellets over the course of a year that are consumed and assimilated by some fishes, with estimated dietary contributions of up to $80 \%$ in $S$. cephalus and European barbel Barbus barbus (Linnaeus, 1758) (Gutmann-Roberts et al. 2017). Correspondingly, understanding how these feeds affect the discrimination factors of the wild fishes that consume them is increasingly important for understanding the role of this trophic subsidy.

In summary, the results suggested that temperature and diet composition have important influences on the discrimination factors of omnivorous fishes and must be incorporated into trophic studies based on mixing models for estimating diet composition. Differences in muscle discrimination between temperatures were partially explained by differences in fish condition that affected $\mathrm{C}: \mathrm{N}$ ratios, although their impact was considered relatively minor. In contrast, dietary influences on discrimination appeared to align to the protein quality hypothesis that suggests that discrimination increases as dietary protein quality decreases. Therefore, for trophic studies on omnivorous fishes, the tissues analysed, the prevailing environmental conditions and the approximate diet composition of the fish all require consideration if the resultant stable isotope data are to subsequently provide robust ecological insights.

Open Access This article is distributed under the terms of the Creative Commons Attribution 4.0 International License (http:// creativecommons.org/licenses/by/4.0/), which permits unrestricted use, distribution, and reproduction in any medium, provided you give appropriate credit to the original author(s) and the source, provide a link to the Creative Commons license, and indicate if changes were made.

\section{References}

Barnes, C., C. J. Sweeting, S. Jennings, J. T. Barry \& N. V. Polunin, 2007. Effect of temperature and ration size on carbon and nitrogen stable isotope trophic fractionation. Functional Ecology 21: 356-362.

Bastos, R. F., F. Corrêa, K. O. Winemiller \& A. M. Garcia, 2017. Are you what you eat? Effects of trophic discrimination factors on estimates of food assimilation and trophic position with a new estimation method. Ecological Indicators 75: 234-241.

Bašić, T., J. R. Britton, M. C. Jackson, P. Reading \& J. Grey, 2015. Angling baits and invasive crayfish as important trophic subsidies for a large cyprinid fish. Aquatic Science 77: $153-160$.
Boecklen, W. J., C. T. Yarnes, B. A. Cook \& A. C. James, 2011. On the use of stable isotopes in trophic ecology. Annual Reviews in Ecology and Systematics 42: 411-440.

Britton, J. R., 2007. Reference data for evaluating the growth of common riverine fishes in the UK. Journal of Applied Ichthyology 23: 555-560.

Brush, J. M., A. T. Fisk, N. E. Hussey \& T. B. Johnson, 2012. Spatial and seasonal variability in the diet of round goby (Neogobius melanostomus): stable isotopes indicate that stomach contents overestimate the importance of dreissenids. Canadian Journal of Fisheries and Aquatic Sciences 69: 573-586.

Busst, G., T. Bašić \& J. R. Britton, 2015. Stable isotope signatures and trophic-step fractionation factors of fish tissues collected as non-lethal surrogates of dorsal muscle. Rapid Communications in Mass Spectrometry 29: 1535-1544.

Busst, G. M. \& J. R. Britton, 2016. High variability in stable isotope diet-tissue discrimination factors of two omnivorous freshwater fishes in controlled ex-situ conditions. Journal of Experimental Biology 219: 1060-1068.

Carassou, L., M. Kulbicki, T. J. Nicola \& N. V. Polunin, 2008. Assessment of fish trophic status and relationships by stable isotope data in the coral reef lagoon of New Caledonia, southwest Pacific. Aquatic Living Resources 21: $1-12$.

Caut, S., E. Angulo \& F. Courchamp, 2008. Caution on isotopic model use for analyses of consumer diet. Canadian Journal of Zoology 86: 438-445.

Copp, G. H., J. R. Britton, Z. Guo, V. R. Edmonds-Brown, J. Pegg, L. Vilizzi \& P. I. Davison, 2017. Trophic consequences of non-native pumpkinseed Lepomis gibbosus for native pond fishes. Biological Invasions 19: 25-41.

Elsdon, T. S., S. Ayvazian, K. W. McMahon \& S. R. Thorrold, 2010. Experimental evaluation of stable isotope fractionation in fish muscle and otoliths. Marine Ecology Progress Series 408: 195-205.

Fagan, K. A., M. A. Koops, M. T. Arts \& M. Power, 2011. Assessing the utility of $\mathrm{C}$ : $\mathrm{N}$ ratios for predicting lipid content in fishes. Canadian Journal of Fisheries and Aquatic Sciences 68: 374-385.

Fry, B., 2002. Stable isotope indicators of habitat use by Mississippi river fish. Journal of the North American Benthological Society 21: 676-685.

Greer, A. L., T. W. Horton \& X. J. Nelson, 2015. Simple ways to calculate stable isotope discrimination factors and convert between tissue types. Methods in Ecology and Evolution 6: 1341-1348.

Grey, J., S. Waldron \& R. Hutchinson, 2004. The utility of carbon and nitrogen isotope analyses to trace contributions from fish farms to the receiving communities of freshwater lakes: a pilot study in Esthwaite Water, UK. Hydrobiologia 524: 253-262.

Grey, J., C. Graham, J. R. Britton \& C. Harrod, 2009. Stable isotope analysis of archived roach (Rutilus rutilus) scales for retrospective study of shallow lake responses to nutrient reduction. Freshwater Biology 54: 1663-1670.

Guo, Z., D. Sheath, F. Amat Trigo \& J. R. Britton, 2016. Comparative functional responses of native and high-impacting invasive fishes: impact predictions for native prey populations. Ecology of Freshwater Fish. https://doi.org/ 10.1111/eff.12297. 
Gutmann-Roberts, C., F. Amat-Trigo, T. Bašić \& J. R. Britton, 2017. Trophic consequences for riverine cyprinid fishes of angler subsidies based on marine derived nutrients. Freshwater Biology 62: 894-905.

Hobson, K. A. \& R. G. Clark, 1992. Assessing avian diets using stable isotopes I: turnover of ${ }^{13} \mathrm{C}$ in tissues. Condor 94 : 181-188.

Hussey, N. E., J. Brush, I. D. McCarthy \& A. T. Fisk, 2010. $\delta^{15} \mathrm{~N}$ and $\delta{ }^{13} \mathrm{C}$ diet-tissue discrimination factors for large sharks under semi-controlled conditions. Comparative Biochemistry and Physiology Part A: Molecular \& Integrative Physiology 155: 445-453.

Hutchinson, J. J. \& C. N. Trueman, 2006. Stable isotope analyses of collagen in fish scales: limitations set by scale architecture. Journal of Fish Biology 69: 1874-1880.

IBM (2013). SPSS v.22. https://www-01.ibm.com/common/ssi/ cgi-bin/ssialias? infotype $=$ an $\&$ subtype $=$ ca $\&$ appname $=$ gpateam\&supplier=897\&letternum=ENUS213-309. Last Accessed 08/09/2017.

Jackson, M. C., R. Allen, J. Pegg \& J. R. Britton, 2013. Do trophic subsidies affect the outcome of introductions of a non-native freshwater fish? Freshwater Biology 58: 2144-2153.

Jackson, M. C., J. R. Britton, J. Cucherousset, Z. Guo, S. Stakenas, R. E. Gozlan, M. G. Godard, J. M. Roussel \& G. H. Copp, 2016. Do non-native pumpkinseed Lepomis gibbosus affect the growth, diet and trophic niche breadth of native brown trout Salmo trutta? Hydrobiologia 772: 63-75.

Jardine, T. D., M. A. Gray, S. M. McWilliam \& R. A. Cunjak, 2005. Stable isotope variability in tissues of temperate stream fishes. Transcations of the American Fisheries Society 134: 1103-1110.

Kiljunen, M., J. Grey, T. Sinisalo, C. Harrod, H. Immonen \& R. I. Jones, 2006. A revised model for lipid-normalizing $\delta 13 \mathrm{C}$ values from aquatic organisms, with implications for isotope mixing models. Journal of Applied Ecology 43: 1213-1222.

Locke, S. A., G. Bulté, M. R. Forbes \& D. J. Marcogliese, 2013. Estimating diet in individual pumpkinseed sunfish Lepomis gibbosus using stomach contents, stable isotopes and parasites. Journal of Fish Biology 82: 522-537.

Macko, S. A., M. L. F. Estep, M. H. Engel \& P. E. Hare, 1986. Kinetic fractionation of stable nitrogen isotopes during amino acid transamination. Geochimica et Cosmochimica Acta 50: 2143-2146.

Martínez del Rio, C. \& B.O. Wolf, 2005. Mass balance models for animal isotopic ecology. In Starck, M. A., T. Wang (eds), Physiological and Ecological Adaptations to Feeding in Vertebrates. Science Publishers, New Hampshire: 141-174.

McClelland, J. W., C. M. Holl \& J. P. Montoya, 2003. Relating low $\delta^{15} \mathrm{~N}$ values of zooplankton to $\mathrm{N}^{2}$-fixation in the tropical North Atlantic: insights provided by stable isotope ratios of amino acids. Deep-Sea Research Part I 50: 849-861.

McCutchan, J. H., W. M. Lewis, C. Kendall \& C. C. McGrath, 2003. Variation in trophic shift for stable isotope ratios of carbon, nitrogen, and sulfur. Oikos 102: 378-390.
Mill, A. C., J. K. Pinnegar \& N. V. C. Polunin, 2007. Explaining isotope trophic-step fractionation: why herbivorous fish are different. Functional Ecology 21: 1137-1145.

Minagawa, M. \& E. Wada, 1984. Stepwise enrichment of ${ }^{15} \mathrm{~N}$ along food-chains: further evidence and the relation between ${ }^{15} \mathrm{~N}$ and animal age. Geochimica et Cosmochimica Acta 48: 1135-1140.

Moore, J. W. \& B. X. Semmens, 2008. Incorporating uncertainty and prior information into stable isotope mixing models. Ecology Letters 11: 470-480.

Pearson, S. F., D. J. Levey, C. H. Greenberg \& C. Martinez del Rio, 2003. Effects of elemental composition on the incorporation of dietary nitrogen and carbon isotopic signatures in an omnivorous songbird. Oecologia 135: 516-523.

Phillips, D. L., 2001. Mixing models in analyses of diet using multiple stable isotopes: a critique. Oecologia 126: 166-170.

Phillips, D. L. \& P. L. Koch, 2002. Incorporating concentration dependence in stable isotope mixing models. Oecologia 130: $114-125$.

Phillips, D. L., R. Inger, S. Bearhop, A. L. Jackson, J. W. Moore, A. C. Parnell, B. X. Semmens \& E. J. Ward, 2014. Best practices for use of stable isotope mixing models in foodweb studies. Canadian Journal of Zoology 92: 823-835.

Pinnegar, J. K. \& N. V. C. Polunin, 1999. Differential fractionation of $\delta^{13} \mathrm{C}$ and $\delta^{15} \mathrm{~N}$ among fish tissues: implications for the study of trophic interactions. Functional Ecology 13: 225-231.

Post, D. M., 2002. Using stable isotopes to estimate trophic position: models, methods, and assumptions. Ecology 83: 703-718.

Post, D. M., C. A. Layman, D. A. Arrington, G. Takimoto, J. Quattrochi \& C. G. Montana, 2007. Getting to the fat of the matter: models, methods and assumptions for dealing with lipids in stable isotope analyses. Oecologia 152: 179-189.

Power, M., K. Guiguer \& D. R. Barton, 2003. Effects of temperature on isotopic enrichment in Daphnia magna: implications for aquatic food-web studies. Rapid Communications in Mass Spectrometry 17: 1619-1625.

Robbins, C. T., L. A. Felicetti \& M. Sponheimer, 2005. The effect of dietary protein quality on nitrogen isotope discrimination in mammals and birds. Oecologia 144: 534-540.

Robbins, C. T., L. A. Felicetti \& S. T. Florin, 2010. The impact of protein quality on stable nitrogen isotope ratio discrimination and assimilated diet estimation. Oecologia 162: 571-579.

Roth, J. D. \& K. A. Hobson, 2000. Stable carbon and nitrogen isotopic fractionation between diet and tissue of captive red fox: implications for dietary reconstruction. Canadian Journal of Zoology 78: 848-852.

Sacramento, P. A., G. I. Manetta \& E. Benedito, 2016. Diettissue discrimination factors $(\Delta 13 \mathrm{C}$ and $\Delta 15 \mathrm{~N})$ and turnover rate in somatic tissues of a neotropical detritivorous fish on C3 and C4 diets. Journal of Fish Biology 89: 213-219.

Sanderson, B. L., C. D. Tran, H. J. Coe, V. Pelekis, E. A. Steel \& W. L. Reichert, 2009. Nonlethal sampling of fish caudal fins yields valuable stable isotope data for threatened and endangered fishes. Transactions of the American Fisheries Society 138: 1166-1177. 
Sinnatamby, R. N., J. E. Bowman, J. B. Dempson \& M. Power, 2007. An assessment of de-calcification procedures for $\delta 13 \mathrm{C}$ and $\delta 15 \mathrm{~N}$ analysis of yellow perch, walleye and Atlantic salmon scales. Journal of Fish Biology 70: 1630-1635.

Sweeting, C. J., J. T. Barry, C. Barnes, N. V. C. Polunin \& S. Jennings, 2007a. Effects of body size and environment on diet-tissue $\delta^{15} \mathrm{~N}$ fractionation in fishes. Journal of Experimental Marine Biology and Ecology 340: 1-10.

Sweeting, C. J., J. T. Barry, N. V. C. Polunin \& S. Jennings, 2007b. Effects of body size and environment on diet-tissue $\delta^{13} \mathrm{C}$ fractionation in fishes. Journal of Experimental Marine Biology and Ecology 352: 165-176.

Syväranta, J., S. Vesala, M. Rask, J. Ruuhijärvi \& R. I. Jones, 2008. Evaluating the utility of stable isotope analyses of archived freshwater sample materials. Hydrobiologia 600: 121-130.

Thomas, S. M. \& T. W. Crowther, 2015. Predicting rates of isotopic turnover across the animal kingdom: a synthesis of existing data. Journal of Animal Ecology 84: 861-870.
Tronquart, N. H., L. Mazeas, L. Reuilly-Manenti, A. Zahm \& J. Belliard, 2012. Fish fins as non-lethal surrogates for muscle tissues in freshwater food web studies using stable isotopes. Rapid Communications in Mass Spectrometry 26: 1603-1608.

Ventura, M. \& E. Jeppesen, 2010. Evaluating the need for acid treatment prior to $\delta 13 \mathrm{C}$ and $\delta 15 \mathrm{~N}$ analysis of freshwater fish scales: effects of varying scale mineral content, lake productivity and $\mathrm{CO}_{2}$ concentration. Hydrobiologia 644: 245-259.

Zuanon, J. A. S., A. C. Pezzato, L. E. Pezzato, J. R. S. Passos, M. M. Barros \& C. Ducatti, 2006. Muscle $\delta 13 \mathrm{C}$ change in Nile tilapia (Oreochromis niloticus): effects of growth and carbon turnover. Comparative Biochemistry and Physiology Part B: Biochemistry and Molecular Biology 145: 101-107. 